\title{
Útvistun verkefna á sviði mannauðsmála á Norðurlöndum
}

\author{
Arney Einarsdóttir og Ingi Rúnar Eðvarðsson ${ }^{1}$
}

\begin{abstract}
Ágrip
Markmið greinarinnar er að bera saman umfang útvistunar á sviði mannauðsmála meðal fyrirtækja og stofnana í Danmörku, Finnlandi, Íslandi og Svípjóð. Varpað er ljósi á umfang útvistunar á kjarnaverkefnum og umsýslu- og rekstrarverkefnum. Umfangið er borið saman milli landanna fjögurra og pað greint á Norðurlöndum í heild eftir premur meginatvinnugreinum. Gagna var aflað meðal forsvarsmanna mannauðsmála í alls 797 fyrirtækjum og stofnunum í löndunum fjórum. Niðurstöður sýna að norræn fyrirtæki og stofnanir útvista í meiri mæli rekstrar- og umsýsluverkefnum á sviði mannauðsmála en faglegum kjarnaverkefnum. Íslensk fyrirtæki útvista almennt í minni mæli en skipulagsheildir í samanburðarlöndunum. Algengast er að verkefnum er snúa að eftirlauna- og lífeyrissjóðsmálum sé útvistað, en breytilegt er á milli landa hvort útvistun launavinnslu eða útvistun upplýsingakerfa á sviði mannauðsmála komi par á eftir í umfangi. Í fagtengdum kjarnaverkefnum er pjálfun og próun helst útvistað í einhverjum mæli. Fyrirtæki og stofnanir í heilbrigðis-, velferðar- og skólamálum og opinberri stjórnsýslu útvista í minni mæli en aðrar greinar. Útvistun launavinnslu er umfangsmest í Finnlandi og í pjónustugreinum pegar Norðurlöndin eru skoðuð í heild.
\end{abstract}

\section{Abstract}

The aim of the paper is to analyse and compare the scope of human resource outsourcing (HRO) in organizations in four Nordic countries, Denmark, Finland, Iceland and Sweden. The scope of outsourcing of non-core administrative HR activities versus core professional HR activities is explored and compared between the four countries. The difference in application between three main industry sectors in the Nordic countries is also analysed. The data was collected among HR managers in a total of 797 organizations in the four participating countries. The results indicate that the Nordic countries outsource non-core administrative activities to a greater extent than core professional HR activities. Icelandic organizations outsource HR activities to a lesser extent than participating organizatons in the other Nordic countries. Organizations in the four Nordic countries outsource mostly in the field of pensions, but it varies between the countries whether payroll administration or Human resource information systems (HRIS) are in second place for outsourcing. In terms of core professional HR activities, training and development are outsourced most. Organizations in healthcare, social services, education and public administration outsource to a lesser extent than other

1 Arney Einarsdóttir er lektor við viðskiptafræðideild Háskóla Íslands. Netfang: arney@hi.is. Ingi Rúnar Eðvarðsson er prófessor við viðskiptafræðideild Háskóla Íslands. Netfang: ingire@hi.is.

This work is licensed under a Creative Commons Attribution 4.0 License.

DOI: https://doi.org/10.24122/tve.a.2019.16.1.3 
sectors, but payroll outsourcing is greatest in scope in the service sector, and in Finland in particular.

\section{JEL flokkun: M12; O15; O57}

Lykilorð: Útvistun mannauðsmála; úthýsing mannauðsmála; mannauðsstjórnun; stefnumiðuð mannauðsstjórnun; Norðurlönd; fagleg kjarnaverkefni; umsýslu- og rekstrarverkefni.

Keywords: HR outsourcing; HRO, Human resource management; Nordic countries; Non-core administrative HR activities; Core professional HR activities.

\section{HR outsourcing (HRO) in the Nordic Countries}

\section{Inngangur}

Mikil umræða hefur verið í mannauðsfræðum um mikilvægi pess að mannauðsstjórar og mannauðsdeildir minnki vægi rekstrar- og umsýsluverkefna á sínu sviði, m.a. til pess að geta orðið virtur stefnumarkandi viðskiptafélagi í stjórnun fyrirtækja (Ulrich \& Brockbank, 2005). Ýmis verkefni og viðfangsefni á sviði mannauðsstjórnunar má telja til kjarnafærni fyrirtækja í peim skilningi að stefnumiðuð mannauðsstjórnun styður við og byggir í auknum mæli upp samkeppnisforskot fyrirtækja í gegnum markvissa uppbygginu á pekkingu, færni og getu mannauðsins (Galanaki, Bourantas, \& Papalexandris, 2008; Ulrich \& Brockbank, 2005). Samkvæmt pessum kenningum ættu skipulagsheildir sem telja að mannauðurinn geti skapað peim samkeppnisforskot að stýra stefnumiðuðum páttum og fagtengdum kjarnaverkefnum mannauðsstjórnunar, eins og ráðningum og pjálfun og próun, styrkri hendi innanhúss. Ýmis umsýslu- og rekstrarverkefni, svo sem launavinnsla, ættu að henta betur til útvistunar (Shen, 2005).

Margt bendir til að útvistun mannauðstengdra verkefna hafi færst í vöxt á liðnum árum víða um heim (Caruth, Haden, \& Caruth, 2013; Žitkienė \& Blusytė, 2015). Leitast hefur verið við að varpa ljósi á umfangið og próunina í ýmsum löndum (Galanaki \& Papalexandris, 2005; Gottardello \& Valverde, 2018; Sheehan, 2009). Margt bendir pó til pess að vöxturinn sé ekki mjög hraður (Shen, 2005). Tiltölulega lítið hefur verið fjallað um útvistun á sviði mannauðsmála hér á landi og annars staðar á Norðurlöndum. Rannsókn í pjónustufyrirtækjum hér á landi árið 2013, sýnir pó að 10,9\% fyrirtækja höfðu fækkað starfsfólki í kjölfar útvistunar pjónustupátta (Ingi Rúnar Eðvarðsson \& Guðmundur Kristján Óskarsson, 2015). Eins hefur komið fram að um helmingur íslenskra fyrirtækja útvistar í einhverjum mæli öflun umsækjenda og um 45\% útvista einhverjum hluta af pjálfun og starfspróun (Arney Einarsdóttir, Katrín Ollafsdóttir, \& Ásta Bjarnadóttir, 2015). Lítið virðist pó almennt vera um rannsóknir á Norðurlöndum á pessu sviði og ekki hefur verið leitast við að bera umfangið og tegund mannauðsverkefna sem er útvistað hér á landi, saman við umfang og framkvæmd á öðrum Norðurlöndum. Ekki hefur heldur verið markvisst leitast við að greina umfang og eðli útvistunar á sviði mannauðsmála sérstaklega í norrænu samhengi, né eftir atvinnugreinum.

Markmiðið hér er pví að varpa ljósi á umfang útvistunar á sviði mannauðsmála á Norðurlöndum, p.e. í Danmörku, Finnlandi, Íslandi og Svípjóð. Í fyrsta lagi er skoðað hvort svokölluðum umsýslu- og rekstrarpáttum sé útvistað í meiri mæli en verkefnum sem falla undir faglega kjarnastarfsemi mannauðsmála á Norðurlöndunum í heild. Í öðru lagi er umfang útvistunar einstakra kjarnaverkefna og umsýslu- og rekstrarverkefna borið saman milli landanna fjögurra. Í priðja lagi er tegund og umfang útvistaðra verkefna skoðað eftir premur meginatvinnugreinum á Norðurlöndum í heild. 


\section{Fræðileg umræða}

\subsection{Stefnumarkandi staða og styrkur mannauðsstjórnunar}

Umræðan og kenningar um veika stöðu mannauðsstjóra í skipulagsheildum og mikilvægi pess að mannauðsstjórar séu stefnumarkandi viðskiptafélagar (e. strategic business partners) er mjög sterk í fræðilegri umræðu um mannauðsstjórnun. Рað á sér í lagi við pegar kemur að stefnumiðaðri mannauðsstjórnun. Rekja má upphafið til ársins 1978 (Legge, 1978) en umræðan fer pó fyrst á flug í lok síðustu aldar (Huselid, 1995; Ulrich, 1997; Ulrich \& Brockbank, 2005) pegar farið er að tala um margpætt hlutverk mannauðsstjóra og mikilvægi pess að peir séu virkir stefnumarkandi viðskiptafélagar í stjórnun fyrirtækja, en ekki bara valdalausir piggjendur og innleiðendur stefnu og breytinga.

Legge (1978) hélt pví fram að starfsmannastjórar pess tíma (seinni hluta síðustu aldar) hafi skort vald til að taka pátt í og hafa áhrif á stefnumarkandi ákvörðunartöku í fyrirtækjum. Peir væru pví fyrst og fremst í viðbragðsstöðu við að slökkva elda og stjórna krísum, eða fastir í umsýslu- og rekstrarverkefnum. Hún taldi að um væri að ræða eins konar vítahring pví valdaleysið drægi jafnframt úr framboði hæfs fólks í störf starfsmannastjóra pess tíma, á sama tíma og hæfnisskortur peirra sem gegna starfinu komi í veg fyrir að peir fái stöðu og vald til áhrifa. En einnig benti hún á skort á viðmiðum til að meta og mæla árangur og afrakstur starfsmannadeilda. Dave Ulrich (1997) kom um tuttugu árum síðar fram með hugmyndina um að mannauðsstjórar pyrftu að vera stefnumarkandi viðskiptafélagar í stjórnun fyrirtækja sem hlaut byr undir báða vængi bæði í fræðaheimum sem og viðskiptalífi.

Hugmyndin snýst með öðrum orðum um að mannauðsstjórar eigi ekki að vera bara viðtakendur og innleiðendur stefnu heldur sé pörf á faglegri og virkri aðkomu peirra og innsýn í mannauð viðkomandi skipulagsheildar við mótun stefnu. Pátttaka og seta mannauðsstjóra í framkvæmdastjórn, eða sambærilegu æðsta teymi er gjarnan ein vísbending um stöðu mannauðsstjóra sem stefnumarkandi viðskiptafélaga. Par að auki er virk pátttaka í mótun viðskiptastefnu, allt frá upphafsstigum stefnumótunarvinnu, gjarnan skilgreind sem önnur mikilvæg vísbending um raunverulegan styrk, stöðu og áhrifavald mannauðsstjórnunar (Glarino, 2013; Reichel \& Lazarova, 2013). Pað er í samræmi við hugmyndir Golden og Ramanujam (1985) um mikilvægi tvíhliða gagnvirkra tengsla og samskipta mannauðsstjórnunar við æðstu stjórnendur í mótun stefnu er hafi jákvæð áhrif á innleiðingu stefnunnar. Nýlegar rannsóknir hafa m.a. sýnt fram á jákvæð áhrif útvistunar á umsýslu- og rekstrarverkefnum á sviði mannauðsmála á stöðu mannauðsstjóra sem stefnumarkandi viðskiptafélaga (Reichel \& Lazarova, 2013; Szierbowski-Seibel \& Kabst, 2018). Í peim rannsóknum eru launavinnsla, eftirlaunasjóðir/lífeyrissjóðir, upplýsingakerfi og svörun almennra fyrirspurna stjórnenda og starfsmanna skilgreind sem umsýsluog rekstrarverkefni. Öflun umsækjenda, mat og val á starfsfólki, pjálfun og próun og tilfærslur og fækkun starfsfólks eru hins vegar skilgreind sem fagtengd kjarnaverkefni.

Eins og áður hefur verið bent á leitast fyrirtæki sem eru stefnumiðuð almennt frekar við að útvista verkefnum sem ekki flokkast undir kjarnastarfsemi peirra. Баð sama má ætla að eigi við um mannauðsmálin og sér í lagi ef mannauðurinn er mikilvægur til að ná samkeppnisforskoti og markmiðið af hálfu mannauðssviðs og/eða mannauðsstjóra er að verða virtur viðskiptafélagi. Pví verður hér leitast við að svara peirri spurningu hvort svokölluðum umsýslu- og rekstrarverkefnum sé útvistað í meiri mæli en peim sem falla undir faglega kjarnastarfsemi mannauðsmála á Norðurlöndum í heild, og umfangið borið saman milli einstakra landa.

\section{2 Útvistun og mannauðsmál}

Útvistun má skilgreina sem framleiðslu og afhendingu á skilgreindri vöru eða pjónustu af aðila eða fyrirtæki utan marka fyrirtækisins (Manning, Massini, \& Lewin, 2008). Hér er stuðst við pá skilgreiningu. Lækkun kostnaðar er algeng ástæða fyrir útvistun í fyrir- 
tækjum og stofnunum og var í auknum mæli tilgreind sem ástæða hér á landi eftir hrun (Ingi Rúnar Eðvarðsson og Guðmundur Kristján Óskarsson, 2015). Fyrirtæki geta einnig verið að leitast við að lækka óbeinan kostnað, t.d. með pví að fækka starfsfólki og einfalda reksturinn og koma á betra kostnaðareftirliti (Kremic, Icmeli Tukel, \& Rom, 2006; Lacity, Willcocks, \& Rottman, 2008; Quinn, 1999). Til að pað sé mögulegt parf pó viðkomandi pjónusta eða vara frá utanaðkomandi aðila að vera ódýrari en innan fyrirtækis. Kostnaðarpættir sem litið er til í pessu samhengi eru gjarnan launakostnaður, flutningar, minni fjárfestingar, ódýrara hráefni, minni kröfur um vinnuaðbúnað o.fl. Í öðrum tilvikum geta fyrirtæki pó verið að leita að mjög sérhæfðri pekkingu og færni sem erfitt er að byggja upp og viðhalda innanhúss.

Útvistun á sviði mannauðsmála (e. Human resource outsouring/HRO) felur í sér að samið er við sérhæfða utanaðkomandi aðila til að sjá um einstök mannauðstengd verkefni (Cooke, Shen, \& McBride, 2005). Markmiðið, líkt og pegar öðrum verkefnum er útvistað, er að fá aðgengi að annaðhvort sérhæfðri tæknilegri pekkingu og pjónustu eða ná fram skilvirkni og sparnaði í mannauðsferlum. Í pví samhengi má pó geta pess að rannsókn á útvistun í 14 Evrópulöndum með gögnum frá premur tímabilum (2000, 2005 og 2010) sýndi jákvæð áhrif á fjölda starfsfólks í mannauðsdeildum með tilliti til heildarfjölda í fyrirtæki (e. HR to employee ratio) eftir pví sem fleiri verkefnum var úthýst (SzierbowskiSeibel \& Kabst, 2018). Рað bendir til pess að markmiðið með útvistun á pessu sviði sé ekki að ná fram skilvirkni og sparnaði. Niðurstöður sýndu einnig fram á hærra hlutfall starfsfólks á hvern starfsmann í mannauðsdeildum í opinbera geiranum en lægra í framleiðslugreinum. Рað gefur vísbendingu um meira skrifræði og umsýslu á sviði mannauðsmála í opinbera geiranum en í einkageiranum. Á hinn bóginn gæti pað gefið vísbendingu um að mannauðurinn sé metinn að meiri verðleikum par en í öðrum greinum, eða að opinberar stofnanir séu ekki að ná fram sambærilegri stærðarhagkvæmni á pessu sviði og einkafyrirtæki.

Önnur ástæða fyrir útvistun er stefnumiðuð, p.e. viðleitni til að auka samkeppnishæfni með pví að einbeita sér að kjarnafærni sinni (lykilpekkingu og sértækum björgum) sem önnur fyrirtæki eigi erfitt með að herma eða líkja eftir (e. imitate) (Lacity et al., 2008; Quinn, 1999). Dæmi um slíka pætti er að standa vörð um lykilpekkingu sem eflir pjónustu við viðskiptavini og nýsköpunargetu og endurskipuleggja eða breyta rekstrinum til að auka sveigjanleika með pað аð markmiði að auka samkeppnisgetu (Quinn, 1999). En fleiri atriði hafa verið tilgreind sem ástæða útvistunar, s.s. eins og að fá aðgang að sérhæfðri eða nýrri tækni, sem og aðgengi að sérhæfðri hæfni og pekkingu sem önnur sérhæfð pjónustueða pekkingarfyrirtæki hafa byggt upp og búa par með yfir. Einnig hefur umræðan verið tengd markmiðum um aukinn sveigjanleika. Eða með öðrum orðum að markmiðið með útvistun sé að draga úr áhættu og gera fyrirtæki betur í stakk búin til pess að takast á við sveiflur á markaði (Kremic et al., 2006; Lacity et al., 2008; Quinn, 1999). Pá má geta pess að pó að ákvörðun um útvistun í minni fyrirtækjum geti oft verið byggð á hentistefnu hverju sinni (Ingi Rúnar Eðvarðsson \& Guðmundur Kristján Óskarsson, 2015) má ætla að ákvörðunin geti jafnvel líka ráðist af staðbundnu framboði og gæðum sérhæfðrar pjónustu í hverju landi, stað eða jafnvel í hverri atvinnugrein fyrir sig.

Margt bendir til pess að útvistun ýmissa pátta mannauðsmála hafi aukist á liðnum áratugum. Bandarísk fyrirtæki hafa haft forystu í peim efnum, en önnur vestræn fyrirtæki fylgja fast á eftir (Galanaki \& Papalexandris, 2007; Klaas, 2008; Szierbowski-Seibel \& Kabst, 2018). Sýnt hefur verið fram á að fyrirtæki útvista á ýmsum sviðum, s.s. í fræðsluog próunarmálum, starfsmannavali, launamálum, frammistöðumati, lögfræðilegum málefnum, upplýsingakerfum og starfslokum (Quinn, 1999; Schlosser, Templer, \& Ghanam, 2006; Sheehan, 2009; Shen, 2005). Ekki er pó alltaf ljóst hversu mikla útvistun er um að ræða og hvort viðkomandi verkefnum sé svo til alfarið útvistað eða hvort pað geti verið í litlum mæli, s.s. eins og í formi ráđgjafar í breytingum o.sv.frv.

Fyrri rannsóknir hafa leitt í ljós að sumir verkpættir og verkefni henti betur til útvistunar 
en aðrir. Almennt má segja að pví einfaldari, afmarkaðri og staðlaðri sem verkefni eru, peim mun betur henta pau til útvistunar. Hið sama má segja ef pau snerta tiltölulega fáa starfsmenn, fela í sér litla áhættu og teljast ekki til kjarnafærni viðkomandi fyrirtækis (Kremic et al., 2006; Quinn, 1999). Mithas og Whitaker (2007) komust að eftirfarandi niðurstöðu, að: (1) Meiri möguleiki er á að útvista störfum sem eru mjög upplýsingarík (hversu miklum tíma er varið í að fást við upplýsingar) í samanburði við annars konar störf. (2) Líkur á útvistun aukast í samræmi við pað hversu auðvelt eða einfalt er að skrá pau, staðla og hluta niður í einingar. (3) Störf og verkefni sem krefjast meiri menntunar og færni eru pví talin síður fallin til útvistunar en störf sem krefjast lítillar menntunar. Skýringin felst í pví að störf sem krefjast mikillar menntunar kalla á hæfni í að greina áskoranir og vandamál, hafa yfirsýn yfir verkefni og ýmis flókin samskipti innanhúss sem erfitt getur verið að útvista. (4) Störf sem purfa litla líkamlega nærveru við fólk henta einnig betur til útvistunar en störf sem krefjast mikillar nærveru. Pannig henta hrein pjónustustörf par sem líkamleg nærvera er mikil illa til útvistunar að mati peirra Mithas og Whitaker (2007). Í pví samhengi má velta fyrir sér hvort eðli starfsemi og starfa hafi áhrif á hvort úthýsing eigi sér stað á sviði mannauðsmála. Á sömu nótum telja Caruth o.fl. (2013) að ákjósanlegast sé að útvista rekstrar- og umsýsluverkefnum á sviði mannauðsmála.

Parfir fyrirtækja virðast einnig ólíkar eftir stærð peirra pegar kemur að útvistun. Sheehan (2009) telur t.d. að pað séu einkum stærri fyrirtæki sem útvisti mannauðsmálum. Рað stafi af pví að eftir pví sem starfsmönnum fjölgi, komi upp sífellt fleiri álitaefni í starfsmannamálum. Einnig nýti minni fyrirtæki ýmsar aðrar leiðir til að hafa áhrif á hegðun starfsmanna en formlegar aðferðir mannauðsstjórnunar sem beitt er í stærri fyrirtækjum. Par má helst nefna náin, tíð og óformlegri samskipti stjórnenda og starfsmanna en einnig er eigandinn jafnvel sá sem ber mesta ábyrgð á starfsmannamálum (Klaas, 2008; Schlosser et al., 2006; Singh \& Vohra, 2009). Minni fyrirtæki og stofnanir eru jafnframt talin síður líkleg til að hafa á að skipa sérhæfðu og sérmenntuðu starfsfólki í mannauðsmálum. Fyrir vikið er talið að pau útvisti aðallega umsýslutengdum verkefnum á sviði t.d. launaog tryggingamála, auk faglegrar mannauðsráðgjafar (Klaas, 2008).

Í ljósi umræðunnar hér að framan er vert að skoða nánar umfang og tegund útvistaðra mannauðsverkefna á Norðurlöndum. Einnig er vert að greina útvistun eftir meginatvinnugreinum. Í fyrsta lagi er frumvinnsla og iðnaður par sem ætla má að verkefnin séu einföld og störfin krefjist takmarkaðrar sérfræðipekkingar og meiri áhersla sé á fasta fjármuni en mannauðinn. Í öðru lagi eru pjónustugreinar par sem líkur eru á pví að mannauðurinn byggi upp samkeppnisforskot fyrirtækja og í priðja lagi heilbrigðis-, velferðar- og skólamál og opinber stjórnsýsla par sem krafist er töluverðar sérhæfingar og sérfræðipekkingar og gera má ráð fyrir að starfsemin par byggist fyrst og fremst á mannauðnum.

\section{Aðferð rannsóknar}

Hér er er gerð grein fyrir úrtaksgerð, framkvæmd, pátttakendum, mælitækjum og tölfræðilegri úrvinnslu rannsóknarinnar.

\subsection{Framkvæmd og pátttakendur}

Gagna var aflað á árunum 2014-2015 meðal mannauðsstjóra í fyrirtækjum og stofnunum með fleiri en 70 starfsmenn á Íslandi, Danmörku, Finnlandi og Svípjóð. Notuð eru gögn úr CRANET-rannsókninni sem er alpjóðleg rannsókn sem er framkvæmd reglubundið á nokkurra ára fresti í um 40 pátttökulöndum. Um er að ræða eina umfangsmestu sjálfstæðu, reglubundnu rannsókn á stefnumörkun og aðferðum á sviði mannauðsmála á alpjóðavísu (Parry, Stavrou-Costea, \& Morley, 2011) og hefur Ísland tekið pátt frá árinu 2003. Úrtakið í hverju landi fyrir sig er tekið úr opinberum skrám, eins og frá ríkisskattstjóra og Fjársýslu ríkisins eða sambærilegum aðilum í hverju pátttökulandi. Leitast er við að spegla allar atvinnugreinar og ná til bæði einkafyrirtækja og opinberra stofnana við úrtaksgerðina. Sam- 
kvæmt bestu vitneskju rannsakenda eru ekki til önnur gögn af sambærilegum gæðum, par sem aflað er upplýsinga með samræmdum hætti meðal mannauðsstjóra og spurt um umfang útvistunar á sviði mannauðsmála á Norðurlöndum. CRANET gögn um útvistun hafa par að auki verið notuð í fjölda rannsókna til að varpa ljósi á umfangið í öðrum löndum og til að svara ýmsum sértækum rannsóknarspurningum (sjá t.d. Galanaki \& Papalexandris, 2005, 2007; Reichel \& Lazarova, 2013; Szierbowski-Seibel \& Kabst, 2018).

Í pessari rannsókn voru notuð gögn um útvistun og svör frá fyrirtækjum og stofnunum á fjórum Norðurlöndum, eða frá alls 797 fyrirtækjum og stofnunum í pátttökulöndunum. Alls voru pátttakendur 119 á Íslandi, 206 í Danmörku, 181 í Finnlandi og 291 í Svípjóð. Svarhlutfallið var 9,7\% í Danmörku, 15,6\% í Finnlandi, 37,9\% á Íslandi og 14,4\% í Danmörku. Konur eru 465 svarenda og karlar 279 talsins, en 54 gáfu ekki upplýsingar um kyn. Meirihluti, eða um $82 \%$ svarenda er með háskólagráðu og voru flestir, eða $41 \%$ með menntun á sviði félagsvísinda og/eða atferlisvísinda, 24\% með prófgráðu í viðskiptafræði en um 7\% í lögfræði. Að meðaltali starfa 1314 starfsmenn í pátttökufyrirtækjunum eða alls rúmlega 1 milljón starfsmanna en meðaltalsfjöldi starfsmanna er lægstur á Íslandi (290). Í ljósi mikils breytileika í stærð er hér pó vert að horfa einnig til miðgildis sem er 173 starfsmenn á Íslandi en hæst í Svípjóð, eða 650 starfsmenn. Um 36\% svarenda starfa hjá opinberri stofnun, en hlutfallið er hæst í Finnlandi (45\%) en lægst í Danmörku (19\%) (sjá töflu 1). Pess má geta að hlutfall peirra sem ekki eru rekin í hagnaðarskyni eða í svokölluðum blönduðum rekstri er nokkuð hátt meðal pátttökufyrirtækja í Danmörku (um 16\%) en lágt meðal pátttökufyrirtækja í Finnlandi (9\%). Petta speglar hugsanlega að rekstrarform t.d. skóla og heilbrigðisstofnana í Danmörku sé fjölbreyttara en í hinum löndunum og að par sé sameignarformið nýtt í meiri mæli fyrir pessar tegundir stofnana. Sjá má jafnframt í töflu 3 að alls falla 30\% pátttökufyrirtækja í Danmörku í flokk heilbrigðis-, velferðar- og skólamála og opinberrar stjórnsýslu. Um 4\% svarenda í heild starfa í skipulagsheildum sem ekki eru reknar í hagnaðarskyni og $4 \%$ í blönduðum rekstri.

Tafla 1. Pátttökufyrirtækin í löndunum fjórum.

\begin{tabular}{lcccc}
\hline & $\begin{array}{c}\text { Fjöldi bátttöku- } \\
\text { fyrirtækja }\end{array}$ & $\begin{array}{c}\text { Meðalfjöldi } \\
\text { starfsmanna }\end{array}$ & $\begin{array}{c}\text { Miðgildi fjölda } \\
\text { starfsmanna }\end{array}$ & $\begin{array}{c}\text { Hlutfall opinberra } \\
\text { stofnana }\end{array}$ \\
\hline Danmörk & 206 & 1247 & 280 & $19 \%$ \\
Finnland & 181 & 1430 & 512 & $45 \%$ \\
Ísland & 119 & 290 & 173 & $37 \%$ \\
Svípjóð & 291 & 1716 & 650 & $41 \%$ \\
\hline Norðurlöndin & $\mathbf{7 9 7}$ & $\mathbf{1 3 1 4}$ & $\mathbf{4 1 0}$ & $\mathbf{3 6 \%}$ \\
\hline
\end{tabular}

Svarendur koma úr öllum greinum atvinnulífsins, eða sjávarútvegi, ferðapjónustu- og fjármálageiranum, framleiðslu- og byggingargeiranum, upplýsingatæknigeiranum, samgöngugeiranum, en einnig úr menntageiranum, heilbrigðispjónustu, rannsóknum og ráðgjöf og opinberri stjórnsýslu. Til að greina hvort munur sé á milli greina eru fyrirtæki og stofnanir hér skilgreind í prjár eftirfarandi meginatvinnugreinar: Frumvinnslu, iðnað, framleiðslu og orkumál, pjónustugreinar (verslun, fjármál, ferðapjónustu o.fl.) og heilbrigðis- velferðar- og skólamál ásamt opinberri stjórnsýslu. Sjá má að hlutfallið í flokknum heilbrigðis-, velferðar- og skólamál og opinber stjórnsýsla er nokkuð hátt í töflu 2, eða á bilinu $30-48 \%$. 
Tafla 2. Hlutföll pátttökufyrirtækja/stofnana í löndunum fjórum - eftir atvinnugreinum.

\begin{tabular}{|c|c|c|c|c|c|}
\hline & Norðurlöndin & Danmörk & Finnland & Ísland & Svípjód \\
\hline Frumvinnsla, iðnaður, framleiðsla og & & & & & \\
\hline orkumál & $25 \%$ & $27 \%$ & $18 \%$ & $25 \%$ & $28 \%$ \\
\hline $\begin{array}{r}\text { pjónustugreinar (verslun, fjármál, } \\
\text { ferđapj. ofl.) }\end{array}$ & $24 \%$ & $33 \%$ & $20 \%$ & $32 \%$ & $17 \%$ \\
\hline $\begin{array}{r}\text { Heilbrigđis-, velferđar- og skólamál og } \\
\text { opinber stjórnsýsla }\end{array}$ & $41 \%$ & $30 \%$ & $48 \%$ & $43 \%$ & $43 \%$ \\
\hline Ađrar greinar & $10 \%$ & $10 \%$ & $14 \%$ & $0 \%$ & $12 \%$ \\
\hline
\end{tabular}

\subsection{Mælitæki og úrvinnsla}

Pátttakendur voru spurðir að pví í hve miklum mæli fyrirtækið eða stofnunin útvistaði alls átta mannauðsverkefnum. Valmöguleikar fyrir hverja spurningu voru á kvarðanum frá 0-4 par sem 0 stendur fyrir ekkert og 4 að öllu leyti/alfarið. Spurt var um eftirfarandi mannauðsverkefni: launavinnslu, eftirlaun/lífeyrissjóði, pjálfun og starfspróun, fækkun starfsfólks, upplýsingakerfi á sviði starfsmannamála, öflun umsækjenda, mat og val á nýju starfsfólki, úrvinnslu og svörun (pjónustu). Pessar aðgerðir eru síðan flokkaðar í annars vegar umsýslu- og rekstrarverkefni (launavinnslu, eftirlaun/lífeyrissjóði, upplýsingakerfi á sviði mannauðsmála og úrvinnslu og svörun almennra fyrirspurna frá stjórnendum og starfsfólki) og hins vegar fagleg kjarnaverkefni á sviði mannauðsmála (öflun umsækjenda, mat og val á nýju starfsfólki, pjálfun og starfspróun starfsfólks og tilfærslu eða fækkun starfsfólks).

Auk pess var í spurningalistanum fjöldi bakgrunnsbreyta um fyrirtækið eða stofnunina sem svarað var fyrir, s.s. eins og atvinnugrein, eignarhald og stærð skipulagsheildar og nokkrar bakgrunnsspurningar er vörðuðu svarandann sjálfan, svo sem kyn, menntun og sæti viðkomandi í framkvæmdastjórn fyrirtækis eða stofnunar. Einnig var spurt um aðkomu að stefnumótun viðskipta- eða fyrirtækjastefnu. Við tölfræðilega greiningu var fyrst og fremst beitt lýsandi tölfræði og tengslagreiningu, ásamt tíðnigreiningu á beitingu einstakra útvistunarverkefna. Útvistunarverkefni voru fyrst flokkuð í tvær tegundir útvistunarverkefna, annars vegar rekstrar- og umsýsluverkefni og hins vegar fagtengd kjarnaverkefni. Við pá flokkun var horft til fyrri rannsókna par sem verkefnin voru einnig flokkuðí annars vegar umsýslu- og rekstrarverkefni og hins vegar fagleg kjarnaverkefni (sjá t.d.í Reichel \& Lazarova, 2013; Szierbowski-Seibel \& Kabst, 2018). Pað er í samræmi við umræðu og kenningar um að mannauðsdeildir purfi að losa sig við umsýslu- og rekstrarverkefni en halda í kjarnaverkefnin til að geta orðið stefnumarkandi viðskiptafélagi.

Pátttakendur voru upplýstir um markmið rannsóknar og peir tóku sjálfviljugir pátt í henni. Að könnun lokinni voru svör aftengd einstökum pátttakendum/fyrirtækjum og pannig tryggð nafnleynd. Framfylgt var pví góðri starfsvenju um siðferði rannsókna.

\section{Niðurstöður}

Niðurstöður (sjá meðaltöl í töflu 3), benda til að á Norðurlöndum sé algengast að útvista eftirlauna- og lífeyrissjóðum, pjálfun og próun og upplýsingakerfum. Á hinn bóginn er svörun almennra fyrirspurna frá stjórnendum og starfsmönnum lítið útvistað. Pessar niðurstöður benda til almennt sterkra tengsla á milli útvistunar á einstökum fagtengdum kjarnaverkefnum á sviði mannauðsmála; tengslin eru sterkust á milli öflunar umsækjenda og mats og vals á starfsfólki $(\mathrm{r}(778)=0,66, \mathrm{p}<0,05)$. Раð bendir til pess að fyrirtæki og stofnanir sem úthýsi á annað borð öflun umsækjenda séu líkleg til að útvista líka í einhverjum 
mæli mati og vali á umsækjendum. Einnig má sjá sterk marktæk tengsl á milli útvistunar á öflun umsækjenda og á pjálfun og próun, sem og á milli útvistunar upplýsingakerfa (HRIS) við útvistun pjálfunar og próunar.

Tafla 3. Lýsandi tölfræði og tengsl á milli umfangs útvistunar verkefna - og við bakgrunn.

\begin{tabular}{|c|c|c|c|c|c|c|c|c|c|c|c|}
\hline & Mt. & 1 & 2 & 3 & 4 & 5 & 6 & 7 & 8 & 9 & 10 \\
\hline \multicolumn{12}{|l|}{ Umsýslu- og rekstrarverkefni } \\
\hline 1. Launavinnsla & 0,86 & 1,0 & & & & & & & & & \\
\hline 2. Eftirlaunasjóđir/lífeyrissjóđir & 1,92 & $0,36 *$ & & & & & & & & & \\
\hline 3. Upplýsingakerfi (HRIS) & 1,30 & $0,20 *$ & $* 0,17 *$ & & & & & & & & \\
\hline 4. Svörun almennra fyrirspurna (stj. \& stm.) & 0,21 & $0,23 *$ & $* 0,09 *$ & 0,09 & $*$ & & & & & & \\
\hline \multicolumn{12}{|l|}{ Fagtengd kjarnaverkefni } \\
\hline 5. Öflun umsækjenda & 0,92 & 0,05 & $0,16 *$ & 0,35 & $* 0,10 *$ & * & & & & & \\
\hline 6. Mat og val á starfsfólki & 0,61 & 0,03 & $0,12 *$ & 0,31 & $* 0,07$ & 0,66 & $*$ & & & & \\
\hline 7. Pjálfun og próun & 1,31 & 0,02 & $0,14 *$ & 0,41 & $* 0,12 *$ & * 0,43 & $* 0,38$ & $*$ & & & \\
\hline 8. Tilfærslur og fækkun starfsfólks & 0,78 & $0,11 *$ & $* 0,20 *$ & 0,21 & $* 0,13 *$ & $* 0,34$ & $* 0,31$ & $* 0,35 *$ & & & \\
\hline \multicolumn{12}{|l|}{ Bakgrunnsbreytur } \\
\hline 9. Stærð & 1314 & $-0,03$ & $-0,01$ & 0,02 & 0,02 & 0,02 & 0,03 & $0,08 *$ & * 0,10 * & & \\
\hline 10. Sæti mstj. i frkvstj. ( $0=$ nei og 1=já) & 0,79 & 0,03 & $0,08 *$ & 0,10 & $* 0,03$ & 0,09 & $* 0,09$ & $* 0,12 *$ & $* 0,09 *$ & $* 0,10 *$ & $*$ \\
\hline 11. Geiri (1=einkaft. og =Opinber st.) & 1,42 & 0,01 & $-0,07$ & 0,13 & $* 0,01$ & $-0,12$ & $*-0,02$ & 0,07 & $-0,14$ * & $* 0,15$ & * $-0,06$ \\
\hline
\end{tabular}

* Marktæk tengsl miðað við $\mathrm{p}<0,05$

$\mathrm{Mt}=$ meðaltal, stj.= stjórnenda og stm.= starfsmanna, HRIS = Upplýsingakerfi á sviði starfsmannamála

Ekki má merkja mikil tengsl milli stærðar fyrirtækja við útvistun einstakra umsýslu- og rekstrarverkefna. Pó eru marktæk tengsl milli stærðar við útvistun tveggja fagtengdra kjarnaverkefna, p.e.a.s. við útvistun pjálfunar og próunar og útvistun er tengist tilfærslum og fækkun starfsfólks. Einnig eru til staðar marktæk jákvæð tengsl útvistunar tveggja umsýslu- og rekstrarverkefna, p.e.a.s. eftirlauna- og lífeyrissjóða og upplýsingakerfa á sviði mannauðsmála við setu mannauðsstjóra í framkvæmdastjórn. Einnig eru jákvæð marktæk tengsl á milli útvistunar á pjálfun og próun og tilfærslum og fækkun starfsfólks við setu mannauðsstjóra í framkvæmdastjórn. Opinberar stofnanir eru samkvæmt pessum frumniðurstöðum aðeins líklegri en einkafyrirtæki til að útvista upplýsingakerfum á sviði mannauðsmála en síður líklegar til að útvista öflun umsækjenda og tilfærslum eða fækkun starfsfólks (sjá töflu 3).

Eins og sjá má í töflu 4 er bæði á heildina litið, sem og í einstökum pátttökulöndum almennt meira um umfangsmikla útvistun að ræða á umsýslu- og rekstrarverkefnum en á fagtengdum kjarnaverkefnum mannauðsmála. Helst er eftirlauna- og lífeyrissjóðum og upplýsingakerfum á sviði mannauðsmála útvistað í miklum mæli eða alfarið, en síst svörun og almennum fyrirspurnum stjórnenda og starfsmanna og mati og vali á umsækjendum. Pessum niðurstöðum ber pví í grófum dráttum saman við niðurstöður og meðaltöl í töflu 3.

Ísland sker sig pó nokkuð frá öðrum Norðurlöndum í pví að fyrirtæki og stofnanir útvista í minni mæli en skipulagsheildir í hinum pátttökulöndunum (sjá töflu 4). Ekkert íslenskt pátttökufyrirtæki útvistar pannig mati og vali á umsækjendum og/eða tilfærslum og fækkunum á starfsfólki. Lítið umfang útvistunar á Íslandi í samanburði við hin pátttökulöndin á við um hvort tveggja umsýslu og rekstrartengd verkefni sem og fagtengd kjarnaverkefni. Finnsk fyrirtæki og stofnanir eru stórtækust í útvistun umsýsluverkefna á sviði launavinnslu (38\%), en sænsk fyrirtæki stórtækust í útvistun upplýsingakerfa á sviði mannauðsmála (38\%), í útvistun kjarnaverkefna á sviði pjálfunar- og próunarverkefna (32\%), í útvistun á öflun umsækjenda (11\%) og í mati og vali á umsækjendum (7\%). 
Tafla 4. Tíðni umfangsmikillar útvistunar verkefna - í miklum mæli eða alfarið.

\begin{tabular}{|c|c|c|c|c|c|}
\hline Umsýslu- og rekstrarverkefni & Norðurlönd & DK & FI & IS & SE \\
\hline Launavinnsla & $19 \%$ & $15 \%$ & $38 \%$ & $8 \%$ & $15 \% *$ \\
\hline Eftirlaunasjóđir/lífeyrissjóđir & $42 \%$ & $50 \%$ & $48 \%$ & $30 \%$ & $38 \% *$ \\
\hline Upplýsingakerfi á sviđi mannauđsmála (HRIS) & $24 \%$ & $9 \%$ & $19 \%$ & $21 \%$ & $38 \% *$ \\
\hline Svörun almennra fyrirspurna (stj. \& stm.) & $3 \%$ & $4 \%$ & $3 \%$ & $2 \%$ & $3 \%$ \\
\hline Meðaltal (umsýslu- og rekstrarverkefni) & $22 \%$ & $19 \%$ & $27 \%$ & $15 \%$ & $23 \%$ \\
\hline
\end{tabular}

\section{Fagtengd kjarnaverkefni}

\begin{tabular}{|c|c|c|c|c|c|}
\hline Öflun umsækjenda & $6 \%$ & $2 \%$ & $3 \%$ & $2 \%$ & $11 \% *$ \\
\hline Mat og val á umsækjendum & $3 \%$ & $0 \%$ & $1 \%$ & $0 \%$ & $7 \% *$ \\
\hline Pjálfun og próun & $16 \%$ & $3 \%$ & $13 \%$ & $4 \%$ & $32 \% *$ \\
\hline Tilfærslur og fækkun starfsfólks & $11 \%$ & $13 \%$ & $10 \%$ & $0 \%$ & $14 \% *$ \\
\hline Meðaltal (fagtengd kjarnaverkefni) & $9 \%$ & $5 \%$ & $7 \%$ & $1 \%$ & $16 \%$ \\
\hline
\end{tabular}

* Marktæk tengsl miðað við $\mathrm{p}<0,05$.

Hvað varðar atvinnugreinarnar (sjá töflu 5), útvista pjónustugreinar launavinnslu (24\%) í meiri mæli en hinar tvær (14\% og 18\%). Hvað varðar fagtengd kjarnaverkefni má einnig merkja að frumvinnslu- og iðnaðargreinar útvista frekar í miklum mæli öflun umsækjenda (9\%) en hinar tvær greinarnar (6\% og 3\%). Pjónustufyrirtækin eru pó stórtækari í útvistun á tilfærslum og fækkun starfsfólks. Skipulagsheildir á sviði heilbrigðis-, velferðar- og skólamála og opinbera stjórnsýslan útvista pó síður í miklum mæli öflun umsækjenda.

Tafla 5. Tíðni umfangsmikillar útvistunar verkefna á Norðurlöndum - eftir greinum.

\begin{tabular}{|c|c|c|c|c|}
\hline Umsýslu- og rekstrarverkefni & $\begin{array}{c}\text { Frumvinnsla, } \\
\text { iðnađur, } \\
\text { framleiðsla } \\
\text { og orkumál }\end{array}$ & $\begin{array}{c}\text { Pjónustugreinar } \\
\text { (verslun, fjármál, } \\
\text { ferðapj. ofl.) }\end{array}$ & $\begin{array}{c}\text { Heilbrigđis-, velferđar- } \\
\text { og skólamál og } \\
\text { opinber stjórnsýsla }\end{array}$ & \\
\hline Launavinnsla & $14 \%$ & $24 \%$ & $18 \%$ & $*$ \\
\hline Eftirlaunasjóđir/lífeyrissjóđir & $39 \%$ & $46 \%$ & $39 \%$ & \\
\hline Upplýsingakerfi á sviđi starfsmannamála & $15 \%$ & $26 \%$ & $28 \%$ & \\
\hline Svörun almennra fyrirspurna (stj. \& stm.) & $3 \%$ & $5 \%$ & $3 \%$ & \\
\hline Meðaltal (umsýslu- og rekstrarverkefni) & $18 \%$ & $25 \%$ & $22 \%$ & \\
\hline \multicolumn{5}{|l|}{ Fagtengd kjarnaverkefni } \\
\hline Öflun umsækjenda & $9 \%$ & $6 \%$ & $3 \%$ & $*$ \\
\hline Mat og val á umsækjendum & $5 \%$ & $3 \%$ & $2 \%$ & \\
\hline Pjálfun og próun & $14 \%$ & $17 \%$ & $18 \%$ & \\
\hline Tilfærslur og fækkun starfsfólks & $11 \%$ & $15 \%$ & $6 \%$ & $*$ \\
\hline Meðaltal (fagtengd kjarnaverkefni) & $10 \%$ & $10 \%$ & $7 \%$ & \\
\hline
\end{tabular}

* Marktæk tengsl miðað við $\mathrm{p}<0,05$. 


\section{Umræða}

Í greininni er leitast við að varpa ljósi á umfang útvistunar á sviði mannauðsmála á Norðurlöndum. Skoðað var hvort umsýslu- og rekstrarverkefnum eða kjarnaverkefnum á sviði mannauðsmála væri útvistað í meira mæli á Norðurlöndum í heild. Einnig var kannað hvort merkja megi mun í verkefnum og umfangi útvistunar milli pátttökulandanna fjögurra, Danmerkur, Finnlands, Íslands og Svípjóðar. Pá var umfang og tegund verkefna sem er úthýst skoðuð eftir premur meginatvinnugreinum í löndunum fjórum.

Niðurstöður benda til pess að fyrirtæki og stofnanir á Norðurlöndum útvisti í meiri mæli, p.e.a.s. mikið eða alfarið, umsýslu- og rekstrarverkefnum en síður fagtengdum kjarnaverkefnum. Pau verkefni sem er útvistað í mestum mæli eru eftirlaunasjóðir/lífeyrissjóðir og par á eftir koma upplýsingakerfi á sviði mannauðsmála og launavinnsla. pessar niðurstöður falla vel að kenningum um að mannauðsdeildir eigi að leggja áherslu á að minnka vægi rekstrar- og umsýsluverkefna til að geta orðið virtur og virkur stefnumarkandi viðskiptafélagi sem hefur raunveruleg áhrif (Legge, 1978; Ulrich \& Brockbank, 2005). Mannauðsdeildir á Norðurlöndunum útvista pví samkvæmt pessu helst umsýsluog rekstrarverkefnum og síður faglegum kjarnaverkefnum á sviði mannauðsmála. Pessar niðurstöður eru í samræmi við almenna umræðu um útvistun og að fyrirtæki eigi síður að útvista páttum sem lúta að kjarnafærni sinni pví erfiðara er fyrir samkeppnisaðila að líkja eða herma eftir peim aðferðum sem lúta að mannauð (Lacity et al., 2008; Quinn, 1999). Par liggi pví tækifærin til að skapa sér samkeppnisforskot á markaði (Shen, 2005).

Niðurstöður benda að auki til pess að af fagtengdum kjarnaverkefnum séu fyrirtæki líklegust til að úthýsa í einhverjum mæli pjálfun og próun par sem meðaltalið er nokkuð hátt (1.31), en prátt fyrir pað pá útvista aðeins $16 \%$ pjálfun og próun í miklum mæli eða alfarið á Norðurlöndunum í heild. Pað er í samræmi við rannsóknir í öðrum löndum, s.s. eins og í Grikklandi (Galanaki \& Papalexandris, 2005) og Ástralíu (Sheehan, 2009). Рað verður pó að teljast athyglisvert í ljósi pess að pjálfun og próun starfsfólks kallar á menntun og færni sem erfitt getur verið að staðla og gæti samkvæmt pví hentað síður til útvistunar.

Í pessu samhengi má pó spyrja hvort framboðið í menntakerfinu á Norðurlöndum, p.e.a.s. ýmiss konar framboð á sí- og endurmenntun í hinu formlega skólakerfi og hjá menntastofnunum (og/eða jafnvel til hliðar við skólakerfið), ásamt sérhæfðu aðlögunarhæfu hilluframboði á ýmiss konar sérhæfðri fræðslu, geri stofnunum og fyrirtækjum auðveldara um vik að útvista verkefnum á pessu sviði til sérhæfðra pjónustuaðila. Par má t.d. nefna sérhæfða málaskóla sem bjóða upp á námskeið í tungumálinu (íslensku, sænsku o. s. frv.) fyrir erlent og/eða innflutt vinnuafl. Einnig er víða boðið upp á MBA-nám og ýmiss konar framhaldsnám í háskólum sem fyrirtæki og stofnanir geta hvatt eða jafnvel styrkt einstaka starfsmenn, stjórnendur og/eða hópa til að sækja. Fyrirtæki geta jafnvel gert samninga við einstaka skóla og ráđgjafarfyrirtæki um starfspróun og uppbyggingu og próun framtíðarstjórnenda fyrirtækisins í stað pess að setja upp eigin fræðsludagskrá og pjálfun innanhúss með ærnum tilkostnaði og áhættu. Par að auki má geta pess að hér á landi, og eflaust á hinum Norðurlöndum líka, bjóða ráðgjafarfyrirtæki upp á svokallaðan fræðslustjóra til leigu. Рað má eflaust að einhverju leyti útskýra með pví að fyrirtæki og stofnanir leiti sér sérhæfðrar pekkingar á sviði pjálfunar og próunar utanhúss pví erfitt geti verið um vik að viðhalda sérhæfðri pekkingu og færni á sviði pjálfunar og próunar á öllum fagtengdum sviðum innanhúss - líkt og raunin er með sérhæfða færni og pekkingu af ýmsum öðrum toga sem er ekki hluti af kjarnafærni viðkomandi fyrirtækis.

Par að auki getur talist athyglisvert að fyrirtæki og stofnanir á Norðurlöndum úthýsa í mjög litlum mæli svörun almennra fyrirspurna frá stjórnendum og starfsfólki. Pau eru pví augljóslega ekki að nýta sér sérhæfða síma- og/eða sjálfvirka og rafræna pjónustu frá öðrum fyrirtækjum á pessu sviði. Рað má hugsanlega rekja til skorts á framboði á sérhæfðri pjónustu á pessu sviði í löndunum. Eða að skýra má pað með pví að sérhæfð innanhússpekking og tengsl og jafnvel nærpjónusta og nærvera í pessum mikilvægu tengslum 
starfsfólks við vinnuveitendur sína, skipti of miklu máli og að erfiðara sé að staðla og flytja hana úr húsi en ætla megi. Рað er pá í samræmi við niðurstöður Mithas og Whitaker (2007) um að slík verkefni falli verr að útvistun. Einnig er hugsanlegt að á Norðurlöndum megi einnig rekja pað til flókinnar starfskjara- og samningagerðar fyrir ólíka starfshópa og við mismunandi stéttarfélög sem geti verið mikilvægt að hafa yfirsýn yfir og viðhalda pekkingu á innanhúss.

Athygli vekur einnig að íslensk fyrirtæki og stofnanir útvista síður en raunin er í hinum löndunum og á pað við um öll verkefnin sem hér eru skoðuð. Sænsk fyrirtæki og stofnanir eru hins vegar afkastamest í útvistun á fagtengdum kjarnaverkefnum í ráðningum, pjálfun og próun og í tilfærslum og fækkun starfsfólks en finnsk fyrirtæki og stofnanir hins vegar afkastamest í útvistun á launavinnslu. Par sem um tiltölulega stöðluð, áhættulítil og dæmigerð upplýsinga- og umsýsluverkefni er að ræða sem ættu að henta vel til útvistunar (Kremic et al., 2006; Quinn, 1999) má spyrja hvort fyrirtæki og stofnanir á hinum Norðurlöndum geti jafnvel tekið Finna sér til fyrirmyndar á pví sviði. Islenskar skipulagsheildir útvista í óverulegum mæli fagtengdum kjarnaverkefnum. Pessar niðurstöður geta pó endurspeglað að einhverju leyti smæð íslenskra fyrirtækja (miðgildi 173 starfsmenn) og stærð peirra sænsku (miðgildi 650 starfsmenn), en samkvæmt niðurstöðum hér eru marktæk tengsl á milli útvistunar tveggja kjarnaverkefna og stærðar, p.e.a.s. útvistunar á pjálfun- og próun og tilfærslum og fækkun starfsfólks. •að er einnig í einhverju samræmi við umræðu um að parfir fyrirtækja geti verið ólíkar í ljósi stærðar og að pau stærri séu almennt líklegri til að útvista verkefnum á sviði mannauðsmála (Sheehan, 2009). Niðurstöður hér benda pó til pess að stærðin skipti fyrst og fremst máli pegar um fagtengd kjarnaverkefni er að ræða. Раð fellur pokkalega að hugmyndum um að smærri fyrirtæki og stofnanir útvisti frekar umsýslutengdum verkefnum en faglegum kjarnaverkefnum (Klaas, 2008; Schlosser et al., 2006; Singh \& Vohra, 2009). Pau smærri eru pví ekki endilega eftirbátar peirra stærri í útvistun umsýsluverkefna. Hér er vert að hafa í huga að fyrirtæki og stofnanir í pessari rannsókn eru öll með fleiri starfsmenn en 70 og pví ekki um að ræða mjög litlar rekstrareiningar.

Með tilliti til pess að $45 \%$ íslenskra fyrirtækja og stofnana útvista pjálfun og próun í einhverjum mæli (Arney Einarsdottir o.fl., 2015) vekur einnig athygli hér að aðeins 4\% pátttökufyrirtækja á Íslandi útvista í miklum mæli eða alfarið í pessum málaflokki. Pað má túlka pannig að algengt sé að fyrirtæki útvisti einstökum námskeiðum og fræðslu eða sértækum verkefnum, eins og parfagreiningu par sem getur verið mikilvægt að fá óháða aðila að, en útvisti síður alfarið allri pjálfun og próun. Ætla má að pað sé vegna pess að pjálfun og próun er hluti af mikilvægri kjarnafærni og pjálfun sem parf að aðlaga að pörfum og stefnu viðkomandi fyrirtækis og stofnun til að hún geti skapað sér raunverulegt samkeppnisforskot.

Niðurstöður leiða einnig í ljós að fyrirtæki og stofnanir í heilbrigðis-, velferðar- og skólamálum og í opinberri stjórnsýslu úthýsa síður í miklum mæli eða alfarið hvoru tveggja umsýslu og rekstrarverkefnum, sem og fagtengdum kjarnaverkefnum. Helst er pó markvert í samanburði milli atvinnugreina að fyrirtæki í pjónustugreinum eru með hvað umfangsmesta útvistun á launavinnslu en frumvinnslu- og iðnaðargreinarnar hins vegar aðeins virkari í útvistun á öflun umsækjenda (9\%) en hinar tvær (3\% og 6\%). Að auki er athyglivert að á sviði heilbrigðis-, velferðar- og skólamála og opinberrar stjórnsýslu, p.e.a.s. á fagsviðum (læknar, kennarar, hjúkrunarfræðingar, félagsráđgjafar o.s.frv.) par sem gera má ráð fyrir að hæfniskröfur séu miklar og sértækar, er öflun umsækjenda útvistað í mjög litlum mæli (3\%). Pað gæti tengst annars vegar prengri lagaramma um ráđningar í opinbera geiranum en í einkageiranum á Norðurlöndum. Eins er hugsanlega auðveldara um vik að ná til viðkomandi fagstétta í gegnum sértækar námsbrautir á ýmsum skólastigum og afla umsækjenda í gegnum formlegt starfsnám á vinnustöðum. Pví getur verið að skipulagsheildir sem starfa á pessum sviðum byggi upp lengri tíma samband við 
pær menntastofnanir sem byggja upp mannauðinn og markaðinn að einhverju leyti á viðkomandi fagsviðum og jafnvel með tengslum í gegnum fagfélög. Мeð öðrum orðum að pað geti verið auðveldara að ná til pessara hópa en annarra.

Pessi rannsókn byggist á könnun sem framkvæmd er með sambærilegu úrtaki og á sama tímabili í fjórum löndum. Pess má pó geta að svarhlutfall er frekar lágt nema á Íslandi og ber að túlka niðurstöður með pað í huga. Pessi rannsókn gefur fyrst og fremst lýsandi innsýn í pað hvers konar verkefnum er útvistað á sviði mannauðsmála á Norðurlöndunum, en ekki er skoðað nánar hvort pað hafi áhrif á aðra pætti s.s. eins og valddreifingu á fagtengdum kjarnaverkefnum til framlínustjórnenda eða hvaða rök eru færð fyrir útvistun einstakra verkefna. Áhugavert væri pví að skoða nánar ástæðurnar fyrir útvistun verkefna á sviði mannauðsmála. Einnig væri vert að rannsaka nánar áhrif útvistunar á annars vegar stöðu og áhrifavald mannauðsstjóra og hins vegar tengsl útvistunar og stöðu og styrk mannauðsstjórnunar við valddreifingu (e. devolvement) verkefna til millistjórnenda á Norðurlöndum.

\section{Lokaord}

Á heildina litið útvista fyrirtæki á Norðurlöndum frekar umsýslu- og rekstrarverkefnum en kjarnaverkefnum á sviði mannauðsmála. Íslensk fyrirtæki og stofnanir útvista pó almennt í minni mæli en önnur norræn fyrirtæki og stofnanir. Sænskar skipulagsheildir eru umfangsmestar í útvistun á sviði mannauðsmála. Рað er pó sammerkt með löndunum fjórum að útvistun umsýslu- og rekstrarverkefna á sviði mannauðsmála er umfangsmeiri en útvistun faglegra kjarnaverkefna á sviði t.d. ráđninga og pjálfunar og próunar. Hvað varðar kjarnaverkefnin er pó umfangið mest á sviði pjálfunar og próunar. Margt bendir til pess að pó megi auka umfang útvistunar á sviði launavinnslu, sér í lagi á Íslandi en einnig í Danmörku og Svípjóð, par sem um nokkuð einfalt, vel afmarkað og staðlað verkefni er að ræða sem hentar vel til útvistunar. Útvistun á pessu sviði ætti einnig að henta vel til að gefa mannauðsdeild og mannauðsstjóra meira svigrúm til að sinna stefnumiðaðri vinnu og faglegri próun er tengist kjarnastarfsemi og kjarnafærni mannauðssviðsins. Раð er pví líklegt til að skerpa samkeppnisforskotið. Einnig benda niðurstöður til pess að fyrirtæki og stofnanir í heilbrigðis-, velferðar- og skólamálum og opinberri stjórnsýslu, sem margar falla að öllum líkindum undir opinberan rekstur (rekstrarform getur pó verið mismunandi milli landa) gætu nýtt sér meira útvistun á pessu sviði. Pað á sér í lagi við um útvistun launavinnslu og jafnvel öflun umsækjenda. Pannig gætu mannauðssviðin jafnvel betur einbeitt sér að faglegum kjarnaverkefnum sínum og stefnumarkandi pátttöku.

\section{Heimildir}

Arney Einarsdóttir, Katrín Ólafsdóttir \& Ásta Bjarnadóttir (2015). Staða og próun mannauðsstjórnunar á Íslandi: Cranet rannsóknin 2015. Reykjavík: Háskólinn í Reykjavík.

Caruth, D. L., Haden, S. S. P., \& Caruth, G. D. (2013). Critical factors in human resource outsourcing. Journal of Management Research, 13(4), 187.

Galanaki, E., Bourantas, D., \& Papalexandris, N. (2008). A decision model for outsourcing training functions: Distinguishing between generic and firm-job-specific training content. The International Journal of Human Resource Management, 19(12), 2332-2351.

Galanaki, E., \& Papalexandris, N. (2005). Outsourcing of human resource management services in Greece. International Journal of Manpower, 26(4), 382-396.

Galanaki, E., \& Papalexandris, N. (2007). Internationalization as a determining factor of HRM outsourcing. The International Journal of Human Resource Management, 18(8), 1557-1567.

Glarino, G. G. (2013). Strategic Human Resource Management: Influences on Perceived Organizational Support and Job Attitudes. International Journal of Business and Social Science, 4(12), 6-15.

Golden, K. A., \& Ramanujam, V. (1985). Between a dream and a nightmare: On the integration of the human resource management and strategic business planning processes. Human Resource Management, 24(4), 429452.

Gottardello, D., \& Valverde, M. (2018). Human Resource Management Outsourcing in Spanish firms: Evolution over time and implication for devolution. Intangible Capital, 14(1), 56-73. 
Huselid, M. A. (1995). The impact of human resource management practices on turnover, productivity, and corporate financial performance. Academy of Management Journal, 38(3), 635-672.

Ingi Rúnar Eðvarðsson \& Guðmundur Kristján Óskarsson. (2015). Útvistun og efnahags-prengingar: Staða mála í pjónustufyrirtækjum. Tímarit um viðskipti og efnahagsmál, 12(1), 1-16.

Klaas, B. S. (2008). Outsourcing and the HR function: an examination of trends and developments within North American firms. The International Journal of Human Resource Management, 19(8), 1500-1514.

Kremic, T., Icmeli Tukel, O., \& Rom, W. O. (2006). Outsourcing decision support: a survey of benefits, risks, and decision factors. Supply Chain Management: An International Journal, 11(6), 467-482.

Lacity, M. C., Willcocks, L. P., \& Rottman, J. W. (2008). Global outsourcing of back office services: lessons, trends, and enduring challenges. Strategic Outsourcing: An International Journal, 1(1), 13-34.

Legge, K. (1978). Power, innovation, and problem-solving in personnel management. MacGraw-Hill Book Company.

Manning, S., Massini, S., \& Lewin, A. Y. (2008). A dynamic perspective on next-generation offshoring: The global sourcing of science and engineering talent. Academy of Management Perspectives, 22(3), 35-54.

Mithas, S., \& Whitaker, J. (2007). Is the world flat or spiky? Information intensity, skills, and global service disaggregation. Information Systems Research, 18(3), 237-259.

Parry, E., Stavrou-Costea, E., \& Morley, M. J. (2011). The Cranet international research network on human resource management in retrospect and prospect. Human Resource Management Review, 21(1), 1-4.

Quinn, J. B. (1999). Strategic outsourcing: leveraging knowledge capabilities. MIT Sloan Management Review, $40(4), 9$.

Reichel, A., \& Lazarova, M. (2013). The effects of outsourcing and devolvement on the strategic position of HR departments. Human Resource Management, 52(6), 923-946.

Schlosser, F., Templer, A., \& Ghanam, D. (2006). How human resource outsourcing affects organizational learning in the knowledge economy. Journal of Labor Research, 27(3), 291-303.

Sheehan, C. (2009). Outsourcing HRM activities in Australian organisations. Asia Pacific Journal of Human Resources, 47(2), 236-253.

Shen, J. (2005). Human resource outsourcing: 1990-2004. Journal of Organisational Transformation and Social Change, 2(3), 275-296.

Singh, M., \& Vohra, N. (2009). Level of formalisation of human resource management in small and medium enterprises in India. The Journal of Entrepreneurship, 18(1), 95-116.

Szierbowski-Seibel, K., \& Kabst, R. (2018). The impact of HR outsourcing and strategic HR integration on the HR-to-employee ratio: An empirical evaluation of the HR function over the last decade. International Journal of Manpower, 39(2), 283-300.

Ulrich, D. (1997). Human resource champions: The next agenda for adding value and delivering results. Boston, MA: Harvard Business School Press.

Ulrich, D., \& Brockbank, W. (2005). The HR value proposition. Boston, MA: Harvard Business Press.golden

Žitkienė, R., \& Blusytė, U. (2015). The management model for human-resource outsourcing among service companies. Intellectual Economics, 9(1), 80-89. 
